\title{
INTERJECTIONS IN SEMARANGAN JAVANESE: A SOCIOPRAGMATIC APPROACH
}

\author{
Raden Arief Nugroho ${ }^{1}$, Nina Setyaningsih ${ }^{2}$ \\ English Department, Faculty of Humanities, Universitas Dian Nuswantoro, Semarang, \\ Indonesia $^{12}$
}

arief.nugroho@dsn.dinus.ac.id ${ }^{1 *}$,nina.setyaningsih@dsn.dinus.ac.id ${ }^{2}$

\begin{abstract}
Interjections are widely applied in Javanese dialect and they characterize particular functions, especially in spoken communication. Semarangan Javanese has some distinct characteristics in its spoken form, especially in its lexical divergence. Consequently, different interjections appear. This research aims to discuss Semarangan Javanese interjections, in terms of the sociopragmatic function applied by Semarangan Javanese speakers in a certain communication context. The researchers applied Jovanovićs interjections classification as the basis of this research. Field research method was used to gather the data by conducting direct observation to research participants. Semarangan Javanese interjections can be explored into three components, namely form, position, and meaning. Based on the findings, the form of Semarangan Javanese interjections are realized from phonological, morphological, and semantic occurrences. These interjections are also recognized in the initial, final, and independent positions. Such variety of meanings from the interjections can be indicated through several contexts that take place in the communication.
\end{abstract}

Keywords : interjections; Semarangan Javanese; Sociopragmatics

\section{Introduction}

Javanese is a member of Austronesian family of languages. It is a language spoken by people in Central Java and East Java. It is also spoken by Javanese people who inhabit Suriname, South America. As a language whose speakers spread around the globe and has various dialects, Javanese has been a rich source for research. The variety spoken in the cultural centers of Yogyakarta and Surakarta is considered to be the standard Javanese. The variety analyzed in this paper is the one spoken in Semarang (the capital city of Central Java), referred to as Semarangan Javanese.

This paper aims to investigate colloquial Semarangan Javanese, particularly interjections used by its speakers. There is relatively little research that has been done on Semarangan Javanese. Moreover, there are also not many studies conducted in the area of interjections, and this is supported by Jovanović (2004), as he says "interjections, as one of the marginal and perhaps least discussed upon classes of words". In addition to this, Hişmanoğlu says that the interjections have been ignored by language teachers who work at the ELT department especially in Turkey (2010). Hence, this study is expected to be a useful resource to those subjects. Javanese, particularly Semarangan dialect, has some distinct characteristics in its spoken dialect, especially in its lexical divergence. As a result, different interjections appear in Semarangan Javanese.

\section{Interjections}

Interjections are words or language features with no actual linguistic or meaning value but are generally applied in the spoken language and represent the condition of a speaker's 
cognitive image. Interjections, as in many languages, are also widely applied in Javanese dialect and they characterize particular functions, especially in spoken communication. However, with the growth of economic, urbanization, and associated area depopulation, dialect anomaly will lead to two ways: first, a community will be vulnerable as dynamic urbanization occurs; second, its linguistic characteristic will lead to "linguistic salad-bowl" as the result of "linguistic melting-pots" ${ }^{2}$. Therefore, it is important to study dialects before they disappear in certain areas.

The discussion of interjections is also linked to their historical background. Historically, interjections have been treated in two different ways: as part of language, or as non-words signifying feelings or states of mind. Interjections have often been seen as minor to linguistic discussion. Nineteenth-century linguists regarded them as para-linguistic, even non-linguistic phenomena, i.e. "between interjection and word there is a chasm wide enough to allow us to say that interjection is the negation of language" (Gesch, 1869:295, as quoted in Jespersen, 1922)); "language begins where interjections end" (Muller, 1836:366). However, there is an opposing party who see interjections as properly linguistic, with rich semantic structures. Ameka (1992) divides interjections into two main classes: primary and secondary interjections. Primary interjections are words that cannot be used in any other sense than as an interjection, such as oops and ouch. These items are non-productive in the sense that they do not inflect and are not movable between word-classes. Furthermore, secondary interjections are "those words which have an independent semantic value but which can be used...as utterances by themselves to express a mental attitude or state" (Ameka 1992:111), such as hell and shit.

\section{Sociopragmatic Focus on Interjections}

According to the function and form, interjections are such linguistics features which have the focus on sociopragmatic aspects. It happens because interjections need some context in order to be understood by the interlocutors. Ziębka-Bialożny (2008:2) argues that "one of the most important elements in the notion of sociopragmatic competence is context, that is circumstances in which a communicative event occurs". Moreover, Leech (1983:13, cited by Ziębka-Bialożny, 2008) explains the notion of context as "any background knowledge assumed to be shared by speaker and hearer and which contributes to the hearer's interpretation of what speaker means by a given utterance." Turning from several researches, as conducted by Ameka (1993), Nübling (2004), or Büyükkantarcioğlu (2006) interjections appear within some specific context and thus they belong to some principles of sociopragmatic. For example, let's take a look at the expression wow. Can you figure out this linguistic expression?

(a) Wow, great!

(b) Wow, that was shit!

Those two expressions may contain some propositions that can be predicted, but the accuracy cannot be adequately captured without visualizing the context of communication. Expression (a) is not always tied up with a compliment and (b) does not always serve a

\footnotetext{
${ }^{1}$ The integration of many different languages spoken by Semarang inhabitants, mixed like a salad.

${ }^{2}$ Heterogeneous society speaking various languages that becomes somewhat homogenous as different components melt together with a common language.
} 
mockery. Imagine that the expression "wow, great!" is uttered by a mother, who just arrives at home after a busy day at the office, realizes her son shatters the room and expression "Wow, that was shit!" is uttered by a best friend of yours who see your best drum solo performance on the stage. Can we still constantly relate expression (a) with a flatter and (b) with an insult? The answer is simply a no.

However wow is a unique case, Wilkins (1992:51) states that "the meaning of wow surely cannot be rigorously defined...however, the range of communicative effects an utterance of wow might give rise to, when combined with different intonations and facial expressions" and this presupposes that interjections are (sometimes) context-dependent which makes it impossible to only guess the meaning of an interjection based on their as word or non-word form. Nevertheless, there are still strict guidelines of the use of interjections in the communication which serve as the boundaries between idiosyncrasies. Examples (a) and (b) above may also serve as the linguistic idiosyncrasies, as another example may depict arghhhh to visualize happiness.

\section{Jovanovic's Classsification of Interjections}

Likewise, there should be a clear basis whether interjections can serve a meaningful communication role. This basis should clearly define the form, position, and meaning of interjections. The analysis on this paper is based on Jovanović (2004). He classifies interjections based on their form, position, and meaning, as summarized in the table 1 :

Table 1: Interjections

\begin{tabular}{|c|c|c|}
\hline Form & Position & Meaning \\
\hline $\begin{array}{l}\text { Interjections } \\
\text { of one to two } \\
\text { syllable } \\
\text { segments }\end{array}$ & $\begin{array}{l}\text { Beginning of } \\
\text { sentence }\end{array}$ & $\begin{array}{l}\text { Anger, } \\
\text { Annoyance, } \\
\text { Approval, } \\
\text { Delight, } \\
\text { Disgust, } \\
\text { Enthusiasm, } \\
\text { Fear, } \\
\text { Impatience, } \\
\text { Irritation, } \\
\text { Joy, Pain, } \\
\text { Pity, } \\
\text { Pleasure, } \\
\text { Sorrow, } \\
\text { Surprise, } \\
\text { Sympathy, } \\
\text { Triumph, } \\
\text { Wonder }\end{array}$ \\
\hline
\end{tabular}

Source: Jovanović (2004)

Jovanović (2004:20) explains that "interjections are sound sequences, typical phrases or clauses which can be realized as utterances". Based on the classification above, interjections may consist of regular vowel and consonant phonemes of the language and on the other hand they may also consist of phonological feature which is positioned outside the 
ordinary system of language, such as the glottal phoneme in ugh. G. Curme (in Jovanović) states that:

Interjections have no distinctive forms which would indicate their function. These words go along the line of the statement that interjections belong to the class of uninflected words, words that do not possess any systematic set of inflectional endings which signal different grammatical categories. On the other hand, they are sometimes made of two or more words or stems. Quite often, interjections that are used in everyday speech present a combination of two independent interjections as is illustrated in Oh, God! Goodness gracious!

As a result, the form of interjections can be distinguished into two forms: 1) an interjection with one or two syllable segments with no particular referents like: aha, oops, ouch, uh-huh; 2) an interjection which is originated from other parts of speech, usually nouns (such as Man! Where have you been?) and adjectives (Great! You did a good job!).

Based on the position of interjections, there are several cases that can be listed due to the information of interjections positions. The first case is that interjections may enter in the beginning of the sentence and this position is often claimed to be independent, which means that they are not grammatically or functionally related to any other word classes of the sentence. The second case comes from J. Sledd (1959:144) who treats interjections as sentence adverbials. The last one says that it is also possible to have interjections at the very end of sentences, separated from the central part by a comma (Jovanović, 2004:21). As being stated before, interjections may serve various meanings in different contexts. Several researches also show a range of meanings which can be interpreted by the listeners in order to avoid the communication from language jungle. Jovanović himself put interjections into some meanings to represent: anger, annoyance, approval, contempt, delight, disgust, enthusiasm, fear, impatience, indignation, irritation, joy, pain, pity, pleasure, relief, sorrow, surprise, sympathy, triumph, and wonder.

Jovanović's classification of interjections is used to give direction of this research and is chosen because it has comprehensive portrait in terms of interjections. As opposed to other researches, such as from Bee Tin (2000), Wee (2002), or Hişmanoğlu (2010), Jovanović's taxonomy completes previous research gap. Bee Tin (2002), with the research title Multi-Dimensionality of Idea Framing in Group Work in Academic Settings, has only discussed meanings or functions of interjections which are classified into the functions of adding, explaining, expanding, concluding, diverging, contrasting, contradicting, counteracting, and challenging, whilst the research conducted by Wee (2002) only explains one interjection in Singlish (Singapore English) and clarifies its function based on the situational context and position. The other research entitled Interjections in English: Neglected but Important Aspect of Foreign Language Learning and Teaching by Hişmanoğlu (2010) explains interjections based on the sociolinguistic, semantic, and pragmatic approach. Like the other researches, Hişmanoğlu does not elucidate the forms and positions of interjections and only exemplifies several interjections occur in classroom language and their functions in foreign language teaching and learning. Referring to the arguments of research gap above, the researchers decide to use Jovanović's classification of interjections to analyze Semarangan Javanese. 


\section{Semarangan Javanese}

Semarangan Javanese is a variety of Javanese which is spoken in Semarang. Hartono (2010:40) says that Semarangan Javanese is a result of acculturation of its speakers. Semarang has been inhabited by five ethnic groups; among others are Javanese, Chinese, Arab, Koja, and Dutch. This process thus has emerged as Semarang develops as a business city. However, with the growth of economic, urbanization, and associated area depopulation, dialect anomaly will lead to two ways: first, a community will be vulnerable as dynamic urbanization occurs; second, its linguistic characteristic will lead to "linguistic salad-bowl" as the result of "linguistic melting-pots". Therefore, it is important to study dialects before they disappear in certain areas.

Although Semarang is the capital city of Central Java province, its position in Javanese culture is inferior to Surakarta. Compared to other Javanese dialects such as Muria (area comprising Kudus, Jepara, and Pati) and Banyumasan and Tegal, geographically Semarangan Javanese has the smallest distribution of speakers. Furthermore, as far as the researchers concern, there is no literature or literary work using Semarangan Javanese. However, as a spoken language, Semarangan Javanese still exists and develops naturally. As Hartono (2010:37) points out, Semarangan Javanese does not develop in all administrative areas of Semarang. Instead, it develops in the neighborhoods between the two main rivers in Semarang: BanjirkanalTimur and Banjirkanal Barat (see Figure 1). Culturally and linguistically, Tugu, Ngaliyan, and Mijen areas are closer to Kendal, while Gunungpati, Tembalang, and Banyumanik are closer to Ungaran. In the eastern part of Semarang, areas such as Gayamsari, Pedurungan, and Genuk have characteristics that are closer to Demak. Therefore, he maintains that the original cultural areas of Semarang are those in between Banjirkanal Barat and Banjirkanal Timur rivers, and extend to the west to KampungPuspanjolo, Krobokan, Karangayu, to Kalibanteng. Three Semarangan enclaves also exist in Mrican, Kapling, and Jatingaleh. Furthermore, Hartono also concludes that the farther an area to Banjirkanal river, the more Semarangan Javanese fades and mixes with the dialect of the closest region, except regions inhabited by original Semarang residents such as Tlogosari, Krapyak, Banyumanik, and a part of Pucanggading. 


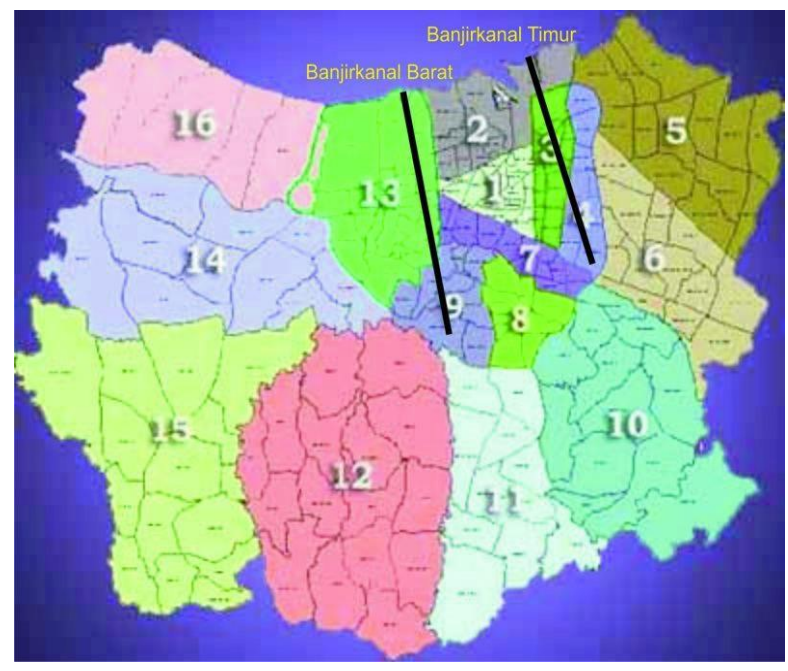

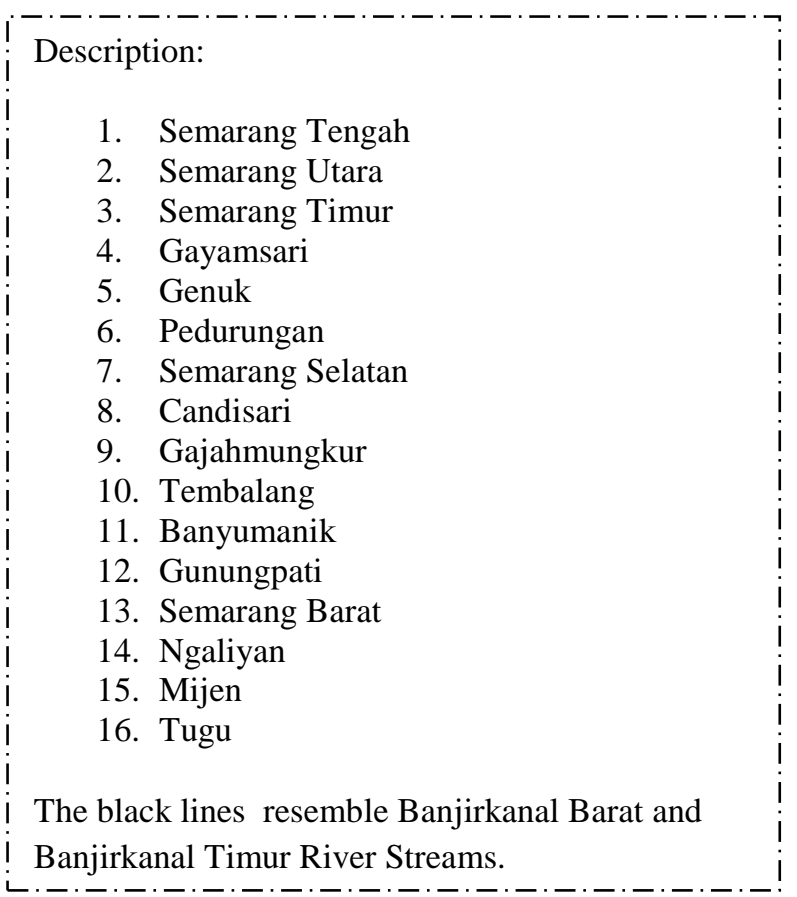

Figure 1. Map of Semarang

Source: Taken and modified from http://asatu.id/files/uploads/2018/03/KECAMATAN-300x237.jpg

\section{Methodology}

The researchers used direct observation technique in their field research. Employing direct observation to some Semarangpeople allowed the researchers to study people in 'their natural' setting without distressing these people's activities as the researchers present. In this field research, the researchers joined in some conversations. In line with Sudaryanto's participant observatory (1993)the researchers were involved in the conversations and sometimes initiated the conversation to fulfill data reliability. In addition, the researchers also employed interview and note taking techniques as to gather supporting data. The participants were selected randomly, but the researchers chose the participants based on diversity basis. As a result, there was a mixture of participants' background in this research. 
In the end, the aspects like age, sex, and academic background were considered as important bases in selecting the participants.

'A research needs to be limited, as a broad analysis of research might produce a shallow analysis. Limitation and delimitation may occur as the parameters of the research. Castetter and Heisler (1977: 38-43) state that "limitation and delimitation establish the boundaries, exceptions, reservations, and qualifications inherent in every study". In addition, Creswell (1994: 110) defines delimitation as a way to narrow the research, while limitation expresses the potential weakness occur in the research. Thus, the limitation of this research concerned with the cognitive process that could not be accessed (viewed) by the researchers; as a result, the researchers tried to classify the use of interjections toward Jovanović's framework from its conversation context.

\section{Findings and Discussion}

Based on the conducted participant observatory, there are several cases of interjections that occur. To clarify the analysis, the findings must be displayed here. Here, in this chapter, the researchers will demonstrate three classifications of interjection i.e. based on form, position, and meaning.

Table 2: Forms of Interjection

\begin{tabular}{|c|c|c|}
\hline No. & Forms & Examples \\
\hline 1 & $\begin{array}{l}\text { Interjections of one to } \\
\text { two syllable segments }\end{array}$ & $\begin{array}{l}\text { ah, yo, ok, nda, to, } \\
\text { moh, as sah, ndes } \\
\text { ah, yoh, yok, heh, } \\
\text { aduh, hah, aaa, } \\
\text { waa, wow, he eh } \\
\text { ya, naah, lha, oh, } \\
\text { hih, ik, hi, Iha, haah, } \\
\text { ya, jon, nda, hore, } \\
\text { alah }\end{array}$ \\
\hline 2 & $\begin{array}{l}\text { Interjections of parts } \\
\text { of speech }\end{array}$ & $\begin{array}{l}\text { ya Allah, modar, } \\
\text { tekke, jancuk, } \\
\text { nggatheli, asem } \\
\text { tenan, asem ya, } \\
\text { asu, celeng, } \\
\text { Astaghfirullah, dadi } \\
\text { thok, dadikke to, } \\
\text { dadekke to ya, blaik } \\
\text { ke, Ihaik, Ihais, yes, } \\
\text { asik, oke to, } \\
\text { Alhamdullilah, wah } \\
\text { kakeane, oke to, sik } \\
\text { ah, moh ah, yo } \\
\text { moh, wejian, } \\
\text { wedrun, sangar, } \\
\text { wagu, ndes }\end{array}$ \\
\hline
\end{tabular}

From Table 2 above, the researchers discover that interjections of parts of speech dominate the findings of forms of interjections. This indicates that there is a high frequency 
of word-like and phrase-like forms, which have referents outside the language. This result may differ from the English interjections which have more groups of interjections proper or one or two syllable segments of interjections in the communication. Furthermore, the interjections of parts of speech shown above may come from various bases, i.e. words (like nouns or adjectives) and phrases. Here, Semarangan Javanese interjections of parts of speech may also be derived (or borrowed) from other languages, like Arabic and English.

Table 3: Positions of Interjection

No. Position Examples

\begin{tabular}{|c|c|c|}
\hline 1 & $\begin{array}{l}\text { Beginning of } \\
\text { sentence }\end{array}$ & $\begin{array}{l}\text { moh, as sah, ndes ah, yoh, yok, dadi } \\
\text { thok, dadekke to, dadekke to ya, heh, } \\
\text { blaik ke, Ihaik, Ihais, Astaghfirullah, } \\
\text { asik, aduh, hah, aaa, waaa, wow, oke } \\
\text { to, he eh ya, naah, Iha, Alhamdullilah, } \\
\text { ya Allah, aduh, tekke, jancuk, nggatheli, } \\
\text { asem tenan, asem ya, asu, celeng, yes, } \\
\text { asik, oke to, modar, wejian, wedrun, } \\
\text { sangar, alah }\end{array}$ \\
\hline 2 & Sentence adverbials & $\begin{array}{l}\text { Ah, yo, ok, nda, to, jon, sik ah, yo moh, } \\
\text { moh ah, oh, wah kakeane, hih, ik, hi, } \\
\text { Iha, haah, ya, nda, ndes, wagu }\end{array}$ \\
\hline
\end{tabular}

The results of Table 3 indicates that most Semarangan Javanese interjections come in the beginning of sentence while there is only one finding indicating the existence of interjections in the end of sentence. This can also indicate that most Semarangan Javanese interjections can position independently as to symbolize sentence mood. This kind of interjection stands without grammatical connection and is loosely linked with the sentence following the interjections and can be identified through longer pause performed by the speaker, like for example: interjection of surprise + (pause)...affirmative sentence (sangar...IP-mu dhuwur) (no meaning connection between the interjection and the following sentence).

The other result shows that interjections as sentence adverbials which follow the nominal-verbal sequence also occurs in the data. This kind of interjections is indicated through shorter pause, and is realized by: (for example) interjections of surprise +(shorter pause) sentence indicating surprise (wagu, kok iso IP-mu dhuwur) (there is meaning connection between the interjection and the sentence). The last result demonstrates that interjections in the end of sentence are realized by the pattern: (for example) sentence indicating declarative + (pause)...interjections of surprise (IP-ku apik, alhamdulillah) (there is meaning connection between the interjection and the sentence).

Table 4: Meanings of Interjection 
Humanika Vol. 26 no 22019 Copyright @2019

Available online di http://ejournal.undip.ac.id/index.php/humanika

\begin{tabular}{|c|c|c|}
\hline No. & Meaning & Examples \\
\hline 1 & Anger & ah, moh, ok, nda, tekke \\
\hline 2 & Annoyance/Irritation & moh, as sah, ndes ah \\
\hline 3 & Enthusiasm & $\begin{array}{l}\text { to yo, dadi tok, dadekke to ya, } \\
\text { dadikke to }\end{array}$ \\
\hline 4 & Approval & $\begin{array}{l}\text { Dadekke to ya, he eh ya, naah, } \\
\text { Iha, jon }\end{array}$ \\
\hline 5 & Delight & $\begin{array}{l}\text { o, Alhamdullilah, hah, wah } \\
\text { kakeane }\end{array}$ \\
\hline 6 & Disgust & heh, hih, lah, tekke, ok \\
\hline 7 & Fear & $\begin{array}{l}\text { blaik ke, Ihais ke, lhaik, } \\
\text { Astaghfirullah, aduh, ya Allah, } \\
\text { modyar }\end{array}$ \\
\hline 8 & Impatience & wah, ik, asem tenan \\
\hline 9 & Joy/Surprise & $\begin{array}{l}\text { sangar, wejian, wedrun, yes, } \\
\text { Alhamdullilah, asik, wagu }\end{array}$ \\
\hline 10 & Pain & $\begin{array}{l}\text { aduh, asem ya, aaa, asu, celeng, } \\
\text { Astaghfirullah }\end{array}$ \\
\hline 11 & Pity/Sympathy & alah, ik, hi, tekke, nda, ya Allah \\
\hline 12 & Pleasure & $\begin{array}{l}\text { hah, yes, Alhamdullilah, oh, Iha, } \\
\text { ya Allah }\end{array}$ \\
\hline 13 & Sorrow & $\begin{array}{l}\text { Iha, hah, ya Allah, haah, jancuk, } \\
\text { nggatheli }\end{array}$ \\
\hline 14 & Triumph & yes, Alhamdullilah, hore, aaa \\
\hline 15 & Wonder & Wah, wow, tekke \\
\hline
\end{tabular}

Table 4 shows that the meaning of Semarangan Javanese interjections almost have the same meaning compared to the interjections of English. But, there are exceptions in the meaning of irritation, surprise, and sympathy. Unlike English interjections that put irritation, surprise, and sympathy interjections in different places, Semarangan Javanese interjections put irritation interjections in the same context as annoyance, surprise interjections in joy, and sympathy interjections in pity. These meanings are shown by the context of situation occurs in the conversation. Some interjections are also displaying words of vulgarity. This is basically affected by the social background of the speakers.

To conclude this section, based on the research data, there are five patterns of Semarangan Javanese interjections as follows:

Pattern 1: Interjections of one to two syllable segments in the beginning of sentence 


\section{Pattern 2: Interjections of parts of speech in the beginning of sentence}

Pattern 3: Interjections of one to two syllable segments as sentence adverbials

\section{Pattern 4: Interjections of parts of speech as sentence adverbials}

\section{Pattern 5: Interjections of one to two syllable segments in the end of sentence}

The analysis of the findings above aims for pattern recognition of Semarangan interjections. Therefore, to justify the analysis, context and co-text of situation are included. First thing first, each pattern will be analyzed individually as to deepen the explanation of Semarangan Javanese interjections and as to show deviation of interjections as well (if any).

\section{Pattern 1}

Pattern 1 suggests the interjections of one to two syllable segments in the beginning of sentence. This kind of pattern supports the proposition that the interjections can stand independently without conforming into the following sentence. Based on the data, there are several interesting cases to be discussed.

Table 5: Example 1 of Pattern 1

\begin{tabular}{l|l|l} 
Sex: M (Male) & Age: 19 & Occupation: Student \\
\hline Context: He is sitting in an important meeting. He needs to \\
get a superb suggestion to solve a problem. Having a serious \\
and tiring meeting for five hours, his friend passes a splendid \\
suggestion. Without thinking too much, his friend's idea is \\
accepted beautifully.
\end{tabular}

Co-text:

"How if we go door-to-door marketing for the next five days to support our financial crisis?"

(Bagaimana jika kita mengadakan penjualan dari pintu ke pintu selama 5 hari berturut-turut untuk mengatasi krisis keuangan kita?)

Response:

He eh ya!

(That's right!)

Meaning of Interjection: Approval

This kind of interjection can stand independently without the support of any following sentence which may express different meaning, for example: interjections of approval + sentence of refusal (as in "that's right, but I cannot accept that"). This may also serve as a sentence mood. Apparently, based on the finding, this kind of interjection always appears on the meaning of approval or positive meaning toward the first speaker 
(interlocutor). In the example above, phonological marker is shown by longer pause performed by the speaker.

\section{Pattern 2}

Interjections of parts of speech in the beginning of sentence are populated into pattern number 2. This type of pattern holds the definition that the interjections cannot stand independently and it has to conform to the following sentence. Based on the occurrence of data, there are two remarkable cases in pattern 2 that can be discussed here.

\section{Table 6: Example 1 of Pattern 2}

\begin{tabular}{l} 
Sex: $\mathrm{M} \quad$ Age: $20 \quad \begin{array}{l}\text { Occupation: } \\
\text { Student }\end{array}$ \\
\hline $\begin{array}{l}\text { Context: He has just got back from work and } \\
\text { sees his sister making out with her boyfriend. }\end{array}$ \\
\hline Response: \\
"Tekke, nggilani ok!" \\
(“Damn, that's disgusting!) \\
\hline Meaning of Interjection: Disgust
\end{tabular}

This interjection shows that the speaker is confirming disgust to the interlocutor. The Semarangan Javanese interjection of 'tekke' becomes the adverbial of the sentence because this interjection explains the sentence uttered by the speaker. In some cases, this interjection performs as the intensifier of sentence. In term of its form, 'tekke' is a clipped form of "utekke" which literally means "the brain" in Javanese. This interjection is commonly used to show emotion in various contexts, such as anger, joy, surprise, disgust, sadness, or fear.

Another case of pattern 2 appears in the example below:

\section{Table 7: Example 2 of Pattern 2}

\begin{tabular}{l} 
Sex: $\mathrm{M}$ Age: $19 \quad$ Occupation: Student \\
\hline Context: He is on his way home and suddenly a nail hits \\
his foot. \\
\hline Response: \\
"Asu!" \\
("Damn") - the literal meaning is 'dog' \\
Meaning of Interjection: Pain
\end{tabular}

From the example above, we can see that male speaker expresses pain with vulgar word. Another example of vulgar word used by male speaker is 'celeng' ['damn'] - with the 
literal meaning 'wild boar'. This configuration may function in a different meaning, such as in "asu...dadi thok!" (interjections of pain + interjections of enthusiasm).

Unlike these explicit words, female speakers respond the pain by expressing religious borrowed word from Arabic 'Astaghfirullah' ['I seek forgiveness from Allah']. This shows that male speakers or particularly young male speakers are used to expressing things with vulgarity.

\section{Pattern 3}

Pattern 3 of Semarangan Javanese interjections presents interjections of one to two syllable segments as sentence adverbials. The result also illustrates that most interjections of one to two syllable segments are performed as sentence adverbials, which means that shorter interjections support the following sentences and function as an intensifier. Here is the discussion:

Table 8: Example 1 of Pattern 3

\begin{tabular}{|c|c|}
\hline Sex: F (Female) & $\begin{array}{l}\text { Age: Occupation: Librarian } \\
24\end{array}$ \\
\hline \multicolumn{2}{|c|}{$\begin{array}{l}\text { Context: She is on her way home and she is watching an old } \\
\text { woman selling fruit in the street. }\end{array}$} \\
\hline \multicolumn{2}{|l|}{ Response: } \\
\hline \multicolumn{2}{|l|}{ "sakke ik" } \\
\hline (“Poor her") & \\
\hline
\end{tabular}

The interjection ' $i k$ ' cannot stand alone and ' $i k$ ' is indicated as a no man's land word. It can occur in a wide range of meaning and from the researchers' point of view the use of ' $i k$ ' occurs as an intensifier of a sentence and thus a sentence will not lose its meaning by the absence of this interjection, but the interjection ' $i k$ ' actually informs and conforms the same idea as the previous/following word/sentence does (as in ' $i \boldsymbol{k}^{\prime}$ + pity = pity, ' $\boldsymbol{i} \boldsymbol{k}$ ' + approval = approval, and so forth). In addition, the researchers also observed that ' $i k$ ' as interjection always occurs in the final position and an interesting fact about this interjection is that it is a flexible interjection as it can be used in most sentences with different meaning with shorter pause as the salient phonological marker.

The interjection ' $o k$ ' is similar to ' $i k$ '. In the following example, ' $o k$ ' demonstrates that the speaker is expressing anger to the interlocutor. The interjection ' $o k$ ' functions as the adverbial of the sentence because this interjection explains the sentence uttered by the speaker. The interjection also intensifies the sentence.

' $l k$ ' and ' $o k$ ' are the most commonly used interjections in Semarangan Javanese. Almost all words spoken by native Semarangan Javanese speakers are followed by these two interjections, even when the speakers speak other languages, especially Indonesian and some Arabic words, in particular the word "Alhamdulillah" (praise God). Hence, these 
interjections become the salient feature of Semarangan Javanese and thus index the speakers' identity.

\section{Table 9: Example 2 of Pattern 3}

Sex: $F$

Age: 24

Occupation: Librarian

Context: She feels tired due to long travel she has made. Suddenly, the phone rings and a friend asks her to replace her friend's shift at work because her friend needs to fulfill her desire to buy some discounted shoes at mall

Co-text:

"Mbak, tulung aku digantikke jogo ya, aku meh tuku sepatu!"

(“Mbak, please take care of my job. Gotta go to the mall for shoes!”)

Response:

"Kok enak kowe. Kene kesel-kesel ok!"

("What the heck. I am dead tired!)

Meaning of Interjection: Anger

\section{Pattern 4}

Interjection of parts of speech as sentence adverbial is included into pattern 4 . This kind of pattern has very low frequency. There are only two findings that can be classified into this pattern. To clarify the pattern, here is the following discussion.

\section{Table 10: Example 1 of Pattern 4}

Sex: $F \quad$ Age: $30 \quad$ Occupation: Lecturer

Context: She just gets surprised by a scandalous story told by her friend.

Co-text:

"Tonggoku bar kawin neh"

(“My neighbor just got married again”)

Response:

"Wagu...mosok alasane koyo ngono"

("silly...it's a silly reason")

Meaning of Interjection: Joy/Surprise 
For some people, this example of interjection is included into sentence mood. This is actually in accordance to Gramley and Pätzold (1992:125) who say that "interjections should include phrases and sentence". Moreover, it can be derived from an adjective and it cannot stand independently without the assistance of preceding or following sentence because it may distort the meaning of 'wagu' itself, since the interjection ' $w a g u$ ' can express the meaning of rejection, impatience, or disgust. In the example above, the meaning of interjection is surprise and the following sentence is also indicating surprise (interjections of surprise + surprise) performed in a short pause between the interjection and following sentence.

Table 11: Example 2 of Pattern 4

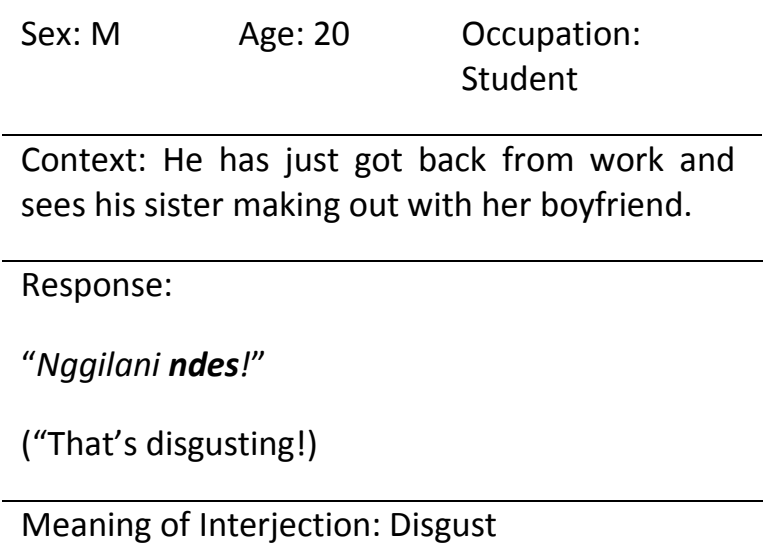

The interjection 'ndes' shown above stands for 'gondes' which has various meanings such as:

1. 'Boy' as its core meaning

2. As a blending of the phrase "gondrong ndeso" (long-haired hillybilly) This word was regarded as rude, but now it becomes a common address term for those who have close relationship, as dude or bro in English.

\section{Pattern 5}

The last pattern depicts the least finding of the data which is interjections of one to two syllable segments in the end of sentence. The discussion is as follows:

Table 12:Example 1 of Pattern 5

\begin{tabular}{l} 
Sex: $\mathrm{F} \quad$ Age: $19 \quad \begin{array}{l}\text { Occupation: } \\
\text { Student }\end{array}$ \\
$\begin{array}{l}\text { Context: She just wins a national scope } \\
\text { competition she has always dreamed of }\end{array}$ \\
\hline Response: \\
"Alhamdullilah...Hore" \\
("Thanks God...Hurray") \\
Meaning of Interjection: Triumph
\end{tabular}


The example of interjection of pattern 5 actually derives from two interjections. The first actually is a borrowed word from Arabic - 'Alhamdullilah' [praise God] - and, through a longer pause, followed by an interjection which actually has the potential of having different intention ('Alhamdullilah'has declarative mood and 'hore' has triumph intention). Moreover, this example of interjections may be classified into a partial borrowing from the English 'hurray'.

\section{Conclusion and Suggestion}

Through this study, the following points could be stressed: The attempt of the authors concerning Jovanović's categorization of interjections can be regarded as a pioneering effort to demonstrate the vast lingual potentiality of this discussion. Thus the major intention in conducting the present work is to draw the scheme of interjections that might depict sociopragmatic and emotional functions of communication.

The reason why the study developed into the categories of Jovanovićs interjections by no means supports the function of interjections as a simplified part of response that also plays an important role in communication. Through this research, the researchers are able to identify five kinds of interjections used in Semarang Javanese, they are: 1) interjections of one to two syllable segments in the beginning of sentence, 2) Interjections of parts of speech in the beginning of sentence, 3) interjections of one to two syllable segments as sentence adverbials, 4) Interjection of parts of speech as sentence adverbial, and 5) interjections of one to two syllable segments in the end of sentence. These interjections can also be expressed through phonological, morphological, and semantic variations. To conclude, by conducting this research the researchers hope that the evidences would uncover the clamshell of interjections in Semarangan Javanese and show the functions of interjections as sociopragmatics and cognitive phenomena.

However, this research needs developing. By using different methods and techniques of data collection the results would probably vary. In addition, the researchers suggest the upcoming researches in interjections to develop the analysis of interjections by getting deeper into the psychological study of interjections or by widening the frame of interjection functions, so the immense functions of interjection in the communication (conversation) can be discovered. Furthermore, this research might be considered trivial in terms of advance consistency of interjections function. By having more time, the variety of functions might appear. Therefore, more time and focus should be generated.

\section{References}

Ameka, Felix K. 1992. "Interjections: The Universal Yet Neglected Part of Speech". Journal of Pragmatics18, no. 2-3: 101-118.

Bee Tin, T. 2000. Multi-Dimensionality of Idea Framing in Group Work in Academic Settings. Language And Education. Vol.14. Pp.223-249.

Benfey, T. 1869. Geschichte der Sprachwissenschaft. München: J.G. Cotta.

Büyükkantarcioğlu, Nalan. 2006. An Analysis of Turkish Interjections in the Context of Reactive Idea Framing. Hacettepe Üniversitesi Edebiyat Fakültesi Dergisi 2006 / Cilt: 23 / Says: 1 / ss. 19-32 
Castetter, William B. dan Heisler, Richard S. 1984. Developing and Defending A Dissertation Proposal Fourth Edition. Graduate School of Education, University of Pennsylvania, Philadelphia.

Crystal, D. 1995 The Cambridge Encyclopedia of Linguistics. Cambridge: Cambridge University Press.

Gramley, S., and K. Patzold. 1992. A Survey of Modern English. London and New York: Routledge

Hişmanoğlu, Murat. 2010. "Interjections in English: Neglected but Important Aspect of Foreign Language Learning and Teaching". Journal of Theory and Practice in Education, 6 (1):17-35

Jespersen, O. 1922. Language: Its Nature, Development and Origin. London: Allen and Unwin.

Jovanović, Vladimir Ž. 2004. "The Form, Position and Meaning of Interjections in English". Linguistics and Literature Vol. 3, No 1, p.p. $17-28$

$\mathrm{Li}$, Conghe. 2005. "A Cognitive-Pragmatic Account of Interjections".US-China Foreign Language Journal volume3, p.p. 65-70.

Hartono. 2011. "Bahasa Semarangan, Bahasa Tutur yang Miskin Literatur". Proceedings of the International Seminar on Language Maintenance and Shift ed. by Timothy Mckinnon, Nurhayati, Agus Subiyanto, M. Suryadi, \&Sukarjo Waluyo, p.p. 37-46. Semarang: Universitas Diponegoro

Quirk, R., S. Greenbaum, J. Leech \& J. Svartvik (eds.). 1985. A Comprehensive Grammar of the English Language. London: Longman

Sapir, E. 1970. Language. London: Hart-Davis Publisher.

Sledd, J. 1959. A Short Introduction to English Grammar. Chicago: Scott, Foresman and Company

Sudaryanto. 1993. Metode dan Aneka Teknik Analisis Bahasa. Yogyakart a: Duta Wacana University Press.

Trask, R.L. 1993. A Dictionary of Grammatical Terms in Linguistics. London: Routledge.

Wee, Lionel. 2002. "Lor in Colloquial Singapore English". Journal of Pragmatics 34, p.p. 711725

Wilkins, D. 1992. "Interjections as Deictics".Journal of Pragmatics 18: 119-158. 